\title{
Efficient regeneration and Agrobacterium-mediated transformation protocol for recalcitrant indica rice (Oryza sativa L.)
}

\author{
Clement Wong Kiing Fook', Lai Kok Song' ${ }^{2}$, Wong Mui Yun ${ }^{1,3}$, Maziah Mahmood ${ }^{1,4 *}$ \\ ${ }^{1}$ Institute of Tropical Agriculture, Universiti Putra Malaysia, 43400, UPM, Serdang, Selangor, Malaysia; ${ }^{2}$ Department of Cell and Molecular \\ Biology, Faculty of Biotechnology and Biomolecular Sciences, Universiti Putra Malaysia, 43400, UPM, Serdang, Selangor, Malaysia; \\ ${ }^{3}$ Department of Plant Protection, Faculty of Agriculture, Universiti Putra Malaysia, 43400, UPM, Serdang, Selangor, Malaysia; ${ }^{4}$ Department of \\ Biochemistry, Faculty of Biotechnology and Biomolecular Sciences, Universiti Putra Malaysia, 43400, UPM, Serdang, Selangor, Malaysia
}

\section{A B S T R A C T}

\begin{abstract}
Rice shoot apices have been selected as the potential explant for genetic transformation since lesser time for regeneration and lower incidence of somaclonal variants were reported as compared to embryogenic callus. Utilizing this explant, efficient regeneration and Agrobacterium transformation protocol have been developed for the recalcitrant Malaysian indica rice, MR219. In this study, $4 \mathrm{mg} / \mathrm{L}$ of KIN was selected as the suitable cytokinin for multiple shoot formation as compared to TDZ and BAP. KIN was able to produce relatively high number of shoots as well as producing good quality shoots with the highest total chlorophyll content, and moderately high total soluble sugar content. In-vitro shoots were successfully acclimatized in glasshouse without signs of infertility. The optimization of the Agrobacterium-mediated protocol revealed that Agrobacterium supervirulent strain EHA101, shoot apices derived from 4 days old seedlings, excised wounded explants, 30 minutes of bacterial immersion time and 72 hours ( 3 days) of co-cultivation gave the highest percentage of plant transiently expressing two reporter genes - GFP and GUS. After 30 days of hygromycin selection and PCR verification of the putative transformants, the transformation efficiency was reported to be $5.83 \%$. The established regeneration system and transformation protocol for MR219 rice shoot apices will serve as an essential fundamental platform for the production of transgenic rice with superior traits.
\end{abstract}

Keywords: Agrobacterium; Indica; Reporter genes; Shoot apices; Rice

\section{INTRODUCTION}

Approximately $90 \%$ of world's rice was produced and consumed in Asia (Ziegler and Barclay, 2008). In particular, $85 \%$ of the world population preferred the long-grained indica varieties and thus, securing $80 \%$ of the world rice trade (Dawe, 2008). With the global population estimated to reach 9.5 billion by 2050 , cereal grain production has to increase by $70 \%$ in order to meet the demands and also to ensure food security is maintained (Bakshi and Dewan, 2013). Furthermore, severe yield loss (30 to 60\%) due to biotic stresses in cereal production (fungal, bacterial, viral, insects and weeds) and abiotic stresses (environmental changes and soil infertility) could easily outrun the global demand causing food supply shortage (Ji et al., 2013). Therefore, new varieties that carry high yield and stress resistant traits are continuously being developed in order to pave towards a more sustainable rice production. In Malaysia, the indica MR219 was developed as a high yielding rice cultivar besides being resistant to blast and bacterial leaf blight (Alias, 2002). Though so, MR219 was still known to be susceptible to fungal diseases (Liew et al., 2012), insects (Ahmed et al., 2011) and abiotic stress such as salinity (Hwte et al., 2011), drought (Saragih et al., 2013) and aluminium/acidity (Shamsuddin et al., 2013).

In order to sustain and enhance rice productivity in times of climate change and disease outbreak, the potential of transgenic rice research has been one of the rapid and efficient alternative as compared to conventional breeding.

\footnotetext{
${ }^{*}$ Corresponding author:

Maziah Mahmood, Institute of Tropical Agriculture, Universiti Putra Malaysia, 43400, UPM, Serdang, Selangor, Malaysia.

Telephone no.: +060389466703, Fax no.: +060389430913, E-mail: maziahm@upm.edu.my

Received: 31 August 2015; Revised: 08 September 2015; Accepted: 09 September 2015; Published Online: 14 September 2015
} 
Various transformation techniques were developed for rice genetic transformation in which the Agrobacterium and bolistic-mediated transformation methods were the most widely employed methods (Altpeter et al., 2005). However, Agrobacterium transformation of Malaysian rice variety remained largely untapped probably due to its recalcitrance towards Agrobacterium. The optimization study on the Agrobacterium method using mature-seed derived embryogenic callus MR219 was only carried out recently (Zuraida et al., 2011). It was reported that a $2.4 \%$ of transformation efficiency was recorded by using somatic embryos and embryogenic calli MR219 as the target tissues (Zuraida et al., 2013).

Most rice transformation protocol involved the use of embryogenic calli as the starting explant. Rice calli induction and regeneration were often cultivar-dependent and time-consuming thereby limiting the transformation efficiency of indica rice varieties (Danilova, 2007). Broadening the choice of rice target tissues that are competent for genetic engineering is a crucial step in the improvement of transformation efficiency. The use of rice shoot apex in Agrobacterium-mediated transformation has been performed for some indica rice cultivars. Utilizing shoot apex as explant for genetic transformation presents several advantages over callus tissues. Shoot apex culture is a reproducible and economically feasible method for producing plants that are free from pathogens (Badoni and Chauhan, 2009). Meristems are often devoid of such systemic pathogen since there are yet any differentiated conducting tissues (Alam et al., 2013). Also, Bairu et al. (2010) revealed that because shoot apex did not undergo dedifferentiation stage as in callus cultures, the chances of obtaining somaclonal variant or genetic mutations were low. Another major advantage is that meristematic tissue in the shoot apex region can develop and regenerate directly into shoots indicating the sustainability and plasticity of the meristematic region (Gamborg et al., 2002; Atak and Celik, 2009). So far, the regeneration of MR219 shoot apex have been studied but the regeneration process was rather lengthy and the survival rate of the shoot apex was very low (Silvarajan et al., 2011). Moreover, no systematic optimization of Agrobacterium-mediated transformation protocol for MR219 shoot apices has been conducted at the moment. Since transformation efficiency depends largely on basic transformation parameters, an optimized transformation protocol is thus important fundamentally prior to gene insertion. Therefore, this study sought to address these problems by developing an efficient and rapid method for the regeneration and Agrobacterium transformation system for MR219 using rice shoot apices as the preferred target tissue.

\section{MATERIALS AND METHODS}

\section{Plant materials}

The recalcitrant indica rice cultivar MR219 was used in this study. Shoot apices derived from 4 days old rice seedlings germinated from mature seeds were used as explants for multiple shoot induction and subsequently used as the target tissue throughout the study.

\section{Sterilization of mature rice seeds}

Mature seeds of MR219 were dehusked, cleaned with household detergent by shaking vigorously for 1 minute and then rinsed thoroughly by running under the tap water. The seeds were surface sterilized with $95 \%$ ethanol for 2 minutes and rinsed with sterile distilled water for 3 times. Later, the seeds were further surface sterilized with commercial Clorox (containing $5 \% \mathrm{NaOCl}$ ) for 30 minutes by agitation on a shaker at $100 \mathrm{rpm}$. The seeds were rinsed with sterile distilled water for 5 times and transferred aseptically to solidified Murashige and Skoog (MS) medium (1962) to allow germination for 4 days.

\section{In-vitro multiple shoot formation}

In-vitro 4 days old rice seedlings were used in this study. Shoots were separated aseptically from the roots and endosperm. The shoot apex tissue was exposed by carefully excising the shoot tip leaving behind approximately $3 \mathrm{~mm}$ of thick basal portion. To study the effect of three different cytokinin - 6-benzyladenine aminopurine (BAP), kinetin (KIN) and thiadizuron (TDZ) concentrations on multiple shoot induction from shoot apices, a range of cytokinin concentration $(1,2,3,4,5$, and $6 \mathrm{mg} / \mathrm{L})$ were added to MS basal medium. Cytokinin free MS medium (MSO) was used as a control medium. The number of shoots formed was recorded after two weeks of culture without subculture. At the same time, the morphological changes including plant height, fresh weight and dry weight of the in-vitro shoots were recorded. The experiment was repeated three times with four rice shoot apices (replicates) for each cytokinin concentration.

\section{Biochemical analysis of in-vitro shoots}

In-vitro shoots obtained from 2 weeks old cultures were subjected to biochemical assay in order to evaluate the quality of in-vitro shoots. The total soluble protein, total soluble sugar and total chlorophyll content in in-vitro shoots were determined. Total soluble protein content was estimated according to Bradford (1976) method with minor modifications. Briefly, samples weighed at $100 \mathrm{mg}$ were homogenized in $1 \mathrm{~mL}$ of freshly prepared extraction buffer containing $100 \mathrm{mM}$ of sodium phosphate buffer, $\mathrm{pH} 8.0$ by using pre-chilled mortar and pestle. After extraction, the homogenates were centrifuged at 11,000 rpm for 20 minutes 
at $4^{\circ} \mathrm{C}$. A volume of $250 \mu \mathrm{L}$ of the supernatant was added to the $250 \mu \mathrm{L}$ of extraction buffer, followed by $5 \mathrm{~mL}$ of the Bradford reagent. The mixture was vortexed before the absorbance reading was taken at $595 \mathrm{~nm}$. The results obtained from the standard curve (bovine serum albumin as the standard) were expressed as $\mathrm{mg}$ protein/g fresh weight (FW). The total soluble sugar content was quantified based on the Somogyi and Nelson method (1944). Fresh leaf sample weighed at $100 \mathrm{mg}$ was homogenized in $10 \mathrm{~mL}$ of deionized water and then incubated in $90^{\circ} \mathrm{C}$ for 10 minutes before being filtered. Meanwhile, Nelson's $0.8 \mathrm{~mL}$ reagent A and $0.2 \mathrm{~mL}$ reagent $\mathrm{B}$ were mixed before the mixture was added to $100 \mu \mathrm{L}$ of cooled sugar fraction. The mixture was incubated at $95^{\circ} \mathrm{C}$ for 30 minutes. The sample was allowed to cool down before adding $1 \mathrm{~mL}$ of arsenomolybdate reagent. Lastly, $6 \mathrm{~mL}$ of deionized water was added and the absorbance was read at $510 \mathrm{~nm}$. The sugar content was estimated from glucose standard curve and expressed as $\mathrm{mg}$ soluble sugar/g fresh weight (FW). The total chlorophyll content was estimated following Arnon's method (Arnon 1949). Fresh leaves weighed at $100 \mathrm{mg}$ were homogenized with $10 \mathrm{~mL}$ of $80 \%(\mathrm{v} / \mathrm{v})$ acetone by using pre-chilled mortar and pestle. The crude extract was then centrifuged at $9000 \mathrm{rpm}$ for 10 minutes. The retained supernatant was used for spectrophotometric measurement at absorbance of $645 \mathrm{~nm}$ and $663 \mathrm{~nm}$ respectively. The total chlorophyll content was calculated using the formula and expressed as $\mathrm{mg} / \mathrm{g}$ fresh weight (FW):

Total Chlorophyll Content $=(20.2 \times$ A645 $)+(8.02 \times$ A663 $) \times$ $(\mathrm{V} / \mathrm{W} \times 1000)$

Where, $\mathrm{V}=$ final volume of crude supernatant in $\mathrm{mL}$ $\mathrm{W}=$ weight of sample in $\mathrm{g}$

All mentioned biochemical assay were repeated three times with four replicates (absorbance readings) taken for each assay.

\section{Rooting, hardening and acclimatization}

Four months old in-vitro single shoots were separated and excised to expose the shoot apex tissue as mentioned previously. The shoot apices were transferred to solidified MSO. After 4 weeks of rooting, well-developed rice plants were washed thoroughly under tap water to remove any agar debris. The plants were transferred to enclosed culture bottles filled with sterile perlite with the addition of $10 \mathrm{~mL}$ Yoshida's nutrient solution (Yoshida et al. 1976). The plants were hardened for additional two weeks. The plants were then moved to a small claypot $(12.5 \mathrm{~cm} \times 17.5 \mathrm{~cm})$ filled with paddy field soil (clay soil) for initial acclimatization for two weeks and lastly, the plants were transplanted onto a larger pot $(38.0 \mathrm{~cm} \times 30.0 \mathrm{~cm})$ to allow room for growth and seed setting.
Optimization of Agrobacterium-mediated transformation parameters

For the optimization study, the parameter to be investigated was varied while the others remained the same as the standard procedure. Five parameters (Agrobacterium strains, seedling age, co-cultivation period, immersion time and wounding types) were optimized. The plasmid pCambia 1304, harbouring the gus $A$ and $m g \not p$ with hptII gene encoding for hygromycin as the selectable marker was used. A colony of $A$. tumefaciens was cultured onto LB broth media supplemented with $50 \mathrm{mg} / \mathrm{L}$ of kanamycin and incubated overnight at $30^{\circ} \mathrm{C}$. Next, the suspension culture was centrifuged at $5000 \mathrm{rpm}$ for 5 minutes, $4^{\circ} \mathrm{C}$. The supernatant was then discarded. The bacterial pellet was resuspended in modified liquid MS medium, pH 5.4 (vir pre-induction medium) supplemented with $10 \mathrm{~g} / \mathrm{L}$ glucose and $100 \mu \mathrm{M}$ acetosyringone until the $\mathrm{OD}_{600}$ reached 0.8 . The bacterial suspension was incubated on a rotary shaker $\left(100 \mathrm{rpm}, 30^{\circ} \mathrm{C}\right)$ for additional 3 hours. The excised shoot apices were immersed in the bacterial suspension for 30 minutes and then blot dry on sterile filter paper. The explants were transferred to co-cultivation medium $(100 \mu \mathrm{M}$ of acetosyringone and $4 \mathrm{mg} / \mathrm{L} \mathrm{KIN})$ and cocultured at $25^{\circ} \mathrm{C}$ for 3 days in a dark growth chamber. Transient expression of GUS and GFP will be recorded for each parameter by determining the percentage of plant expressing both reporter genes.

\section{Transient expression study of GUS and GFP}

The GUS assay procedure was performed according to Jefferson (1987). Explants were immersed in GUS gene assay buffer which contained $100 \mathrm{mM}$ of sodium phosphate buffer (pH 7.0), $10 \mathrm{mM} \mathrm{Na}{ }_{2}$ EDTA, $1 \mathrm{mM}$ of potassium ferricyanide, $1 \mathrm{mM}$ of potassium ferrocyanide, $1 \mathrm{mM}$ of $\mathrm{X}$-gluc and $0.1 \%$ Triton-X. The mixture was incubated at $30^{\circ} \mathrm{C}$ for 48 hours. GUS expression in the form of blue precipitate was observed using a light stereomicroscope (Zeiss, Axio). GFP-expressing shoot apices were observed with a fluorescence microscope (Leica MZFL III) equipped with GFP 2 filter (Excitation filter: 480/40 nm) to mask the red auto-fluorescence of the chlorophyll. A Leica DC 200 imaging camera was connected to the fluorescence microscope for real-time image capturing via the Leica DC Viewer software. This study was repeated three times with 15 shoot apices (replicates) being examined for transient GFP and GUS expressions. Results were expressed as percentage of plant expressing GFP/GUS:

$\%$ plant expressing GFP/GUS = No. of plants expressing $/$ total number of plants $\mathrm{x} 100 \%$

\section{Selection of putative transformants}

After 3 days of co-cultivation, shoot apices was transferred to MS selection medium supplemented with $4 \mathrm{mg} / \mathrm{L} \mathrm{KIN}$, 
$20 \mathrm{mg} / \mathrm{L}$ hygromycin and $200 \mathrm{mg} / \mathrm{L}$ of cefotaxime. The shoot apex were cultured under selection pressure for 15 days and transferred to the same selection media for another 15 days. After 30 days of selection, these transformed lines were subjected to GUS and GFP expression analyses and molecular analyses to detect the presence of transgenes.

\section{PCR confirmation}

The plant genomic DNA from the putative transformants was isolated according to Staub et al. (1996). A PCR reaction mixture containing 50 ng DNA (purity: $1.7-2.0$ ), $1 \mathrm{x}$ of DreamTaq ${ }^{\mathrm{TM}}$ PCR buffer, $200 \mu \mathrm{M}$ of dNTP mixture, $0.6 \mu \mathrm{M}$ of forward and reverse primers, 1.25 units of DreamTaq ${ }^{\mathrm{TM}}$ polymerase and sterile ultrapure water (Millipore, Merck) to a final volume of $25 \mu \mathrm{L}$ was briefly vortex. The specific forward and reverse primers for GFP (GFPF 5'-ATGGTAGATCTGACTAGTAAAGGAG-3', GFPR 5'-TCAAGAAGGACCATGTGGTC-3') and GUS (GUSF 5'-TAGAGATAACCTTCACCCGG-3', GUSR 5'-CGCGAAAACTGTGGAATTGA-3') were used in this study. The PCR running condition for GFP and GUS gene was as follows: initial denaturation for 3 minutes, followed by 35 cycles of denaturation at $94^{\circ} \mathrm{C}$ for 1 minute, annealing at $60^{\circ} \mathrm{C}$ for 1 minute and elongation at $72^{\circ} \mathrm{C}$ for 2 minutes, and a final elongation at $72^{\circ} \mathrm{C}$ for 7 minutes. All PCR products were analyzed through $0.8 \%$ gel electrophoresis.

\section{Statistical analysis}

All experiments were repeated 3 times. The data obtained from each set of experiment was analyzed by one-way ANOVA in a completely randomized design. Mean values were compared by Duncan's multiple range test at $5 \%(\mathrm{p}=0.05)$ significance level, using software SPSS version 20.0 (SPSS Inc. USA).

\section{RESULTS}

\section{In-vitro multiple shoot induction}

Determination of a suitable cytokinin and its optimal concentration are crucial as rice shoot apices responded differently towards different cytokinins. Three different cytokinins - KIN, BAP and TDZ were evaluated for their potential of inducing multiple shoots from shoot apices. For each tested cytokinin, the shoot numbers increased from $1 \mathrm{mg} / \mathrm{L}$ to $4 \mathrm{mg} / \mathrm{L}$ but decreased thereafter at concentrations of 5 and $6 \mathrm{mg} / \mathrm{L}$. Results showed that $4 \mathrm{mg} / \mathrm{L}$ of TDZ produced the most number of shoots (6.50 shoots/explant), followed by $4 \mathrm{mg} / \mathrm{L} \mathrm{KIN} \mathrm{and}$ $3 \mathrm{mg} / \mathrm{L}$ of BAP which produced 5.50 and 5.25 shoots per explant respectively as compared to MSO (cytokinin-free media) which only produced 1.33 shoots/explant (Fig. 1, 2). Results showed that fresh and dry weight of shoots at $4 \mathrm{mg} / \mathrm{L}$ TDZ were recorded to be the highest $(0.35 \mathrm{~g}$ and

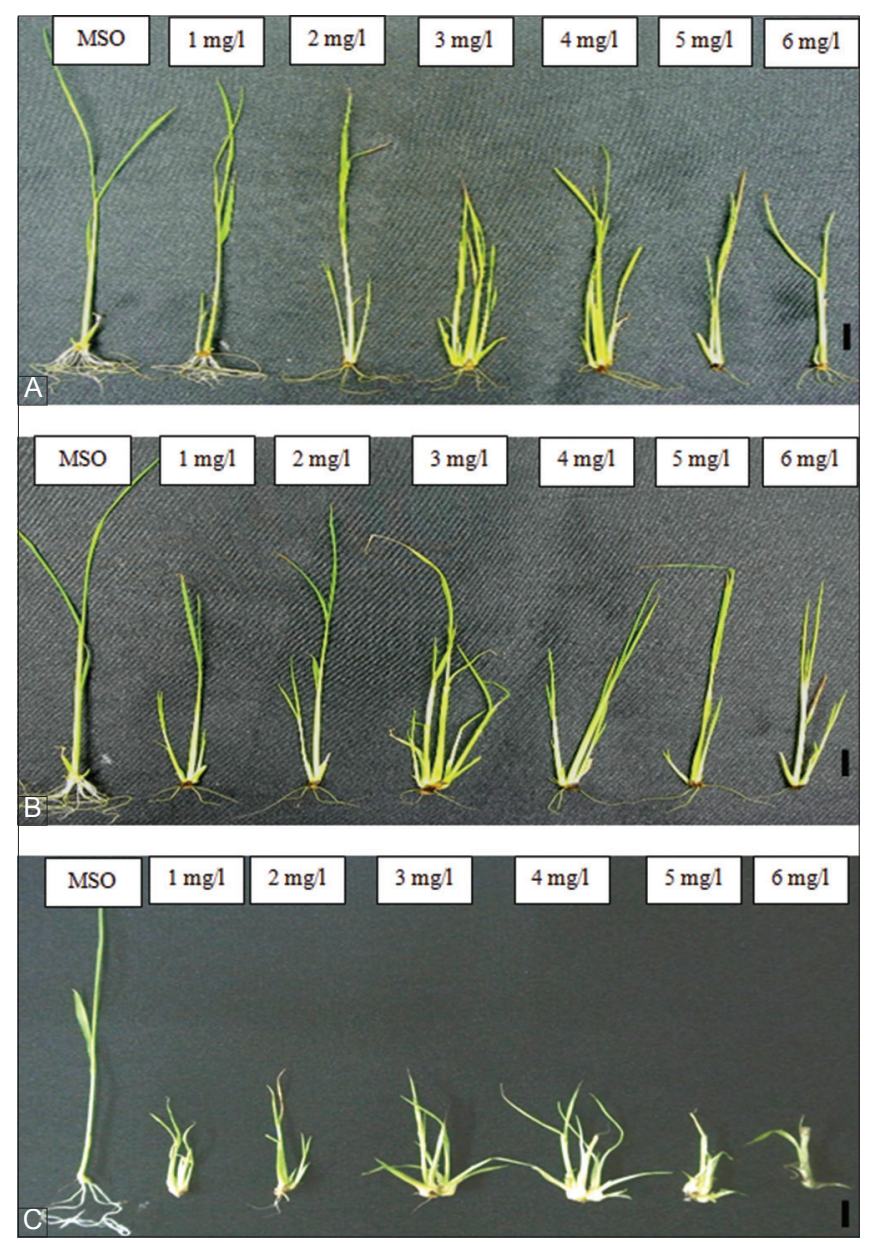

Fig 1. The effect of (A) KIN: Kinetin, (B) BAP: 6-benzyladenine aminopurine and (C). TDZ: Thiadizuron from 1 to $6 \mathrm{mg} / \mathrm{l}$ on the multiple shoot induction from MR219 rice shoot apices after 2 weeks of culture. Bar represents $1 \mathrm{~cm}$.

$0.03 \mathrm{~g}$ respectively). Fresh and dry weight for in-vitro shoots cultivated on $3 \mathrm{mg} / \mathrm{L} \mathrm{BAP}(0.29 \mathrm{~g}$ and $0.03 \mathrm{~g})$ and $4 \mathrm{mg} / \mathrm{L}$ KIN (0.27 $\mathrm{g}$ and $0.02 \mathrm{~g}$ ) were lower than TDZ but higher than MSO $(0.16 \mathrm{~g}$ and $0.017 \mathrm{~g})$. The height of the in-vitro shoots cultured in all three cytokinins supplemented media were found to be shorter than those cultured in MSO $(15.67 \mathrm{~cm})$. The plant height of in-vitro shoots cultured in 1 to $6 \mathrm{mg} / \mathrm{L}$ of KIN and BAP did not differ significantly. An average height of $9.5 \mathrm{~cm}$ of in-vitro shoots were produced in $1 \mathrm{mg} / \mathrm{l}$ of BAP but subsequent concentrations of 2 to $6 \mathrm{mg} / \mathrm{L}$ produced shoots with height ranging from $6.50 \mathrm{~cm}$ to $7.50 \mathrm{~cm}$. The same goes for all tested concentrations of KIN in which plant height measured was at a range of 6.25 to $6.85 \mathrm{~cm}$. Shoots produced in TDZ supplemented media were significantly shorter than KIN and BAP with a decreasing plant height trend (from $4.60 \mathrm{~cm}$ to $3.40 \mathrm{~cm}$ ) as TDZ concentrations increased from 1 to $6 \mathrm{mg} / \mathrm{L}$ (Fig. 2).

\section{Biochemical changes of in-vitro shoots}

Different cytokinins were shown to produce varied morphological changes in in-vitro rice shoot apices. 


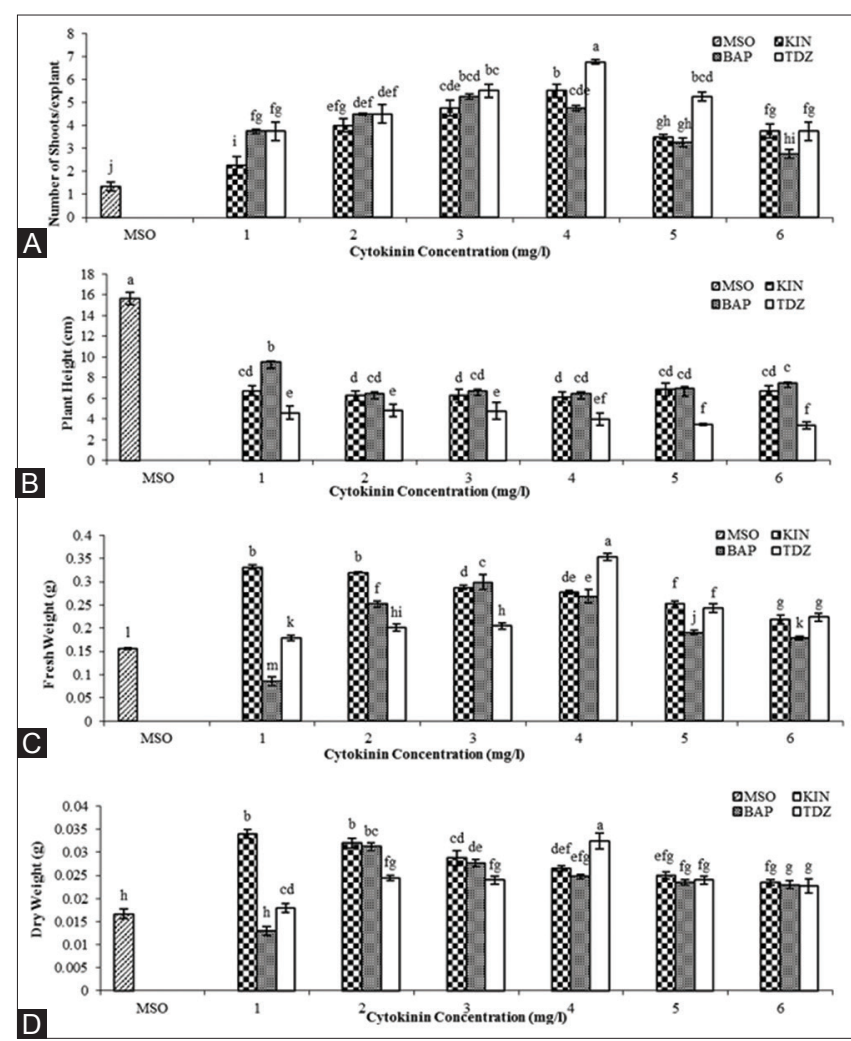

Fig 2. The effect of different cytokinins from 1 to $6 \mathrm{mg} / \mathrm{l}$ on the (A) number of shoots, (B) plant height, (C) fresh weight and (D) dry weight of in-vitro shoots after 2 weeks of culture. Data represents mean \pm standard deviation $(n=4)$. Different letters indicate the values are significantly different $(p \leq 0.05)$.

Correlating these changes with the biochemical activity of the shoots as influenced by cytokinins could help identify the suitable cytokinin to produce quality in-vitro shoots. As shown in Fig. 3, the in-vitro shoots cultured in KIN media generally showed the highest total chlorophyll content from $1 \mathrm{mg} / \mathrm{L}(0.39 \mathrm{mg} / \mathrm{g} \mathrm{FW})$ to $6 \mathrm{mg} / \mathrm{L}(0.49 \mathrm{mg} / \mathrm{g}$ FW) whereas BAP (0.17 to $0.18 \mathrm{mg} / \mathrm{g} \mathrm{FW}$ ) and TDZ ( 0.20 to $0.18 \mathrm{mg} / \mathrm{g} \mathrm{FW}$ ) showed lower total chlorophyll content from 1 to $6 \mathrm{mg} / \mathrm{L}$. Based on the optimal cytokinin concentration that produced the most shoots, $4 \mathrm{mg} / \mathrm{L}$ KIN generated shoots with the highest total chlorophyll content $(0.43 \mathrm{mg} / \mathrm{g} F W)$ which was followed by $3 \mathrm{mg} / \mathrm{L}$ BAP $(0.22 \mathrm{mg} / \mathrm{g} F W)$ and $4 \mathrm{mg} / \mathrm{L} \mathrm{TDZ}(0.15 \mathrm{mg} / \mathrm{g} \mathrm{FW})$. The total soluble sugar content of in-vitro shoots did not indicate drastic changes in all tested concentrations of KIN (0.13 to $0.11 \mathrm{mg} / \mathrm{g} \mathrm{FW}$ ) and TDZ (0.11 to $0.12 \mathrm{mg} / \mathrm{g}$ FW) except for BAP (0.04 to $0.10 \mathrm{mg} / \mathrm{FW}$ ) (Fig. 3). Shoots cultured in MSO generally contained lower soluble sugar content $(0.09 \mathrm{mg} / \mathrm{g} \mathrm{FW})$ as compared to shoots induced by exogenous cytokinin. In-vitro shoots proliferated in $4 \mathrm{mg} / \mathrm{L}$ of TDZ contained the highest total soluble sugar content ( $0.12 \mathrm{mg} / \mathrm{g} \mathrm{FW}$ ). In $4 \mathrm{mg} / \mathrm{L} \mathrm{KIN} \mathrm{and} 3 \mathrm{mg} / \mathrm{L} \mathrm{BAP}$, the soluble sugar content was measured at $0.10 \mathrm{mg} / \mathrm{g} \mathrm{FW}$ and $0.09 \mathrm{mg} / \mathrm{g}$ FW respectively. Referring to Fig. 3, the total

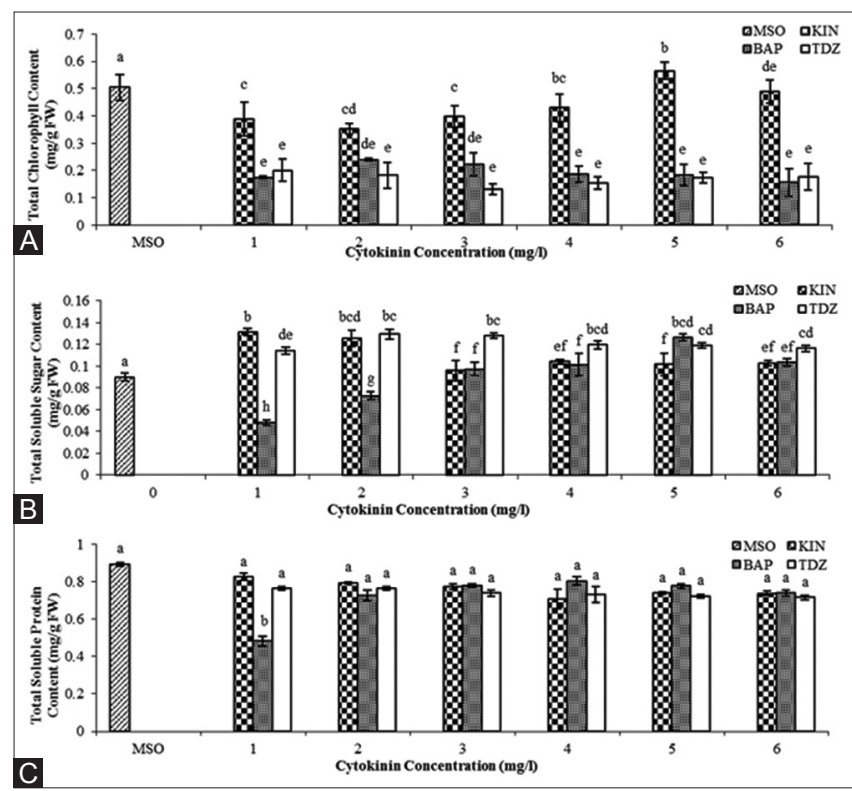

Fig 3. The effect of different cytokinins from 1 to $6 \mathrm{mg} / \mathrm{l}$ on the biochemical changes - (A) total chlorophyll, (B) total soluble sugar, (C) total soluble protein content of in-vitro shoots after 2 weeks of culture. Data represents mean \pm standard deviation $(n=4)$. Different letters indicate the values are significantly different $(p \leq 0.05)$.

soluble protein content measured for in-vitro shoots in KIN ( 0.83 to $0.73 \mathrm{mg} / \mathrm{g} \mathrm{FW}$ ) and TDZ (0.76 to $0.71 \mathrm{mg} / \mathrm{g} \mathrm{FW}$ ) did not show significant changes from concentrations of $1 \mathrm{mg} / \mathrm{L}$ to $6 \mathrm{mg} / \mathrm{L}$. Shoot cultures in BAP media exhibited a significant increase of soluble protein content from $1 \mathrm{mg} / \mathrm{L}$ $(0.48 \mathrm{mg} / \mathrm{g} \mathrm{FW})$ to $2 \mathrm{mg} / \mathrm{L}(0.79 \mathrm{mg} / \mathrm{g} F W)$. However, there were no considerable changes of soluble protein content in in-vitro shoots cultured in concentrations of BAP ranging from $3 \mathrm{mg} / \mathrm{L}$ to $6 \mathrm{mg} / \mathrm{L}$ (0.78 to $0.74 \mathrm{mg} / \mathrm{g} \mathrm{FW})$.

\section{Optimization of genetic transformation parameters}

Agrobacterium strain EHA 101 produced plantlets with the highest percentage of GFP (38.0\%) and GUS (35.0\%) which was followed by strain EHA 105 with 33.0\% GFP and 27.5\% GUS expression respectively. (Fig. 4A). Agrobacterium strain LBA4404 produced shoots with the lowest transient GFP (15.0\%) and GUS expressions $(22.5 \%)$. Shoot apices derived from different seedling age also demonstrated varied percentage of plant transiently expressing GFP or GUS. Rice shoot apices obtained from 4 days old seedlings gave the highest percentage of GFP $(35.0 \%)$ and GUS (33.5\%) expression which was followed by 5 days old shoot apices (22.5\% GFP and $25.0 \%$ GUS). Three days old (12.5\% GFP and 7.5\% GUS) and 6 days old shoot apices $(12.5 \%$ and $11.5 \%)$ indicated the lowest percentage of gene expression (Fig. 4B). In this study, young ( 3 days old) and old (6 days old) rice shoot apices showed necrotic symptoms after bacterial immersion which eventually led to explant death during the co-cultivation stage. Additional wounding of rice shoot apices did 
not result in high percentage expression of the reporter genes. Excised shoot apices further wounded with scalpel and needle recorded lower expression of GFP $(13.0 \%$ and $18.0 \%)$ and GUS (11.3\% and $10.0 \%)$ respectively as compared to the excised explant which gave $33.0 \%$ GFP and 47.5\% GUS expression (Fig. 4C). The optimal immersion period for Agrobacterium strain EHA101 was 30 minutes with $35.0 \%$ of GFP and $33.0 \%$ of GUS gene expression (Fig. 4D). The percentage of expression was found to the lowest at 15 minutes (GFP 7.5\% and GUS $15.0 \%$ ) perhaps because there was insufficient time for bacterial attachment to occur. Prolonging the immersion period to 45 minutes (GFP 17.5\% AND GUS $19.0 \%$ ) and 60 minutes (GFP 7.5\% and GUS 18.0\%) yielded lower reporter genes expression respectively. An optimal co-cultivation condition determines the success of T-DNA incorporation into the plant genomic DNA. The percentage of GFP and GUS expression increased from 12 hours $(9.0 \%$ and $3.75 \%), 24$ hours $(18.0 \%$ and $15 / 0 \%)$ to 48 hours $(25.0 \%$ and $15.0 \%)$ and the percentage expression was at the highest at 72 hours with $38.0 \%$ GFP and $35.0 \%$ GUS expression per plant (Fig. 4E). At 96 hours, the percentage expression of the reporter genes dropped drastically (GFP $13.0 \%$ and GUS 12.5\%).

\section{PCR confirmation of transgene GFP and GUS}

Validating the presence of transgene in the putative transformants via PCR is crucial to eliminate any escapees that survived during the hygromycin selection stage. After the selection of putative transformants in $20 \mathrm{mg} / \mathrm{l}$ of hygromycin, the isolated genomic DNA of the putative transformants were used for PCR verification of transgene (Fig. 6D, E). PCR products for GFP ( 678 bp) and GUS ( $\sim 640$ bp) were successfully amplified using the gene specific primers (Fig. 5A, B). From the 120 shoot apices, a total of 7 hygromycin resistant rice plantlets were tested to be pcr positive for both GFP and GUS reporter genes. The extracted pCambia 1304 and genomic DNA from untransformed rice plant (without pCambia 1304) both served as the positive and negative control respectively. Stable expression of GFP and GUS was also observed in plantlets after being rooted in IBA supplemented MS media for a month (Fig. 6F, G). By using the optimized Agrobacterium transformation protocol, the transformation efficiency was reported to be $5.83 \%$.

\section{DISCUSSION}

The common function of cytokinin was known to stimulate cell division and overcome apical dominance which eventually led to the initiation of shoot multiplication (van Staden et al., 2008). In this study, TDZ was shown to be superior to KIN and BAP by producing the most

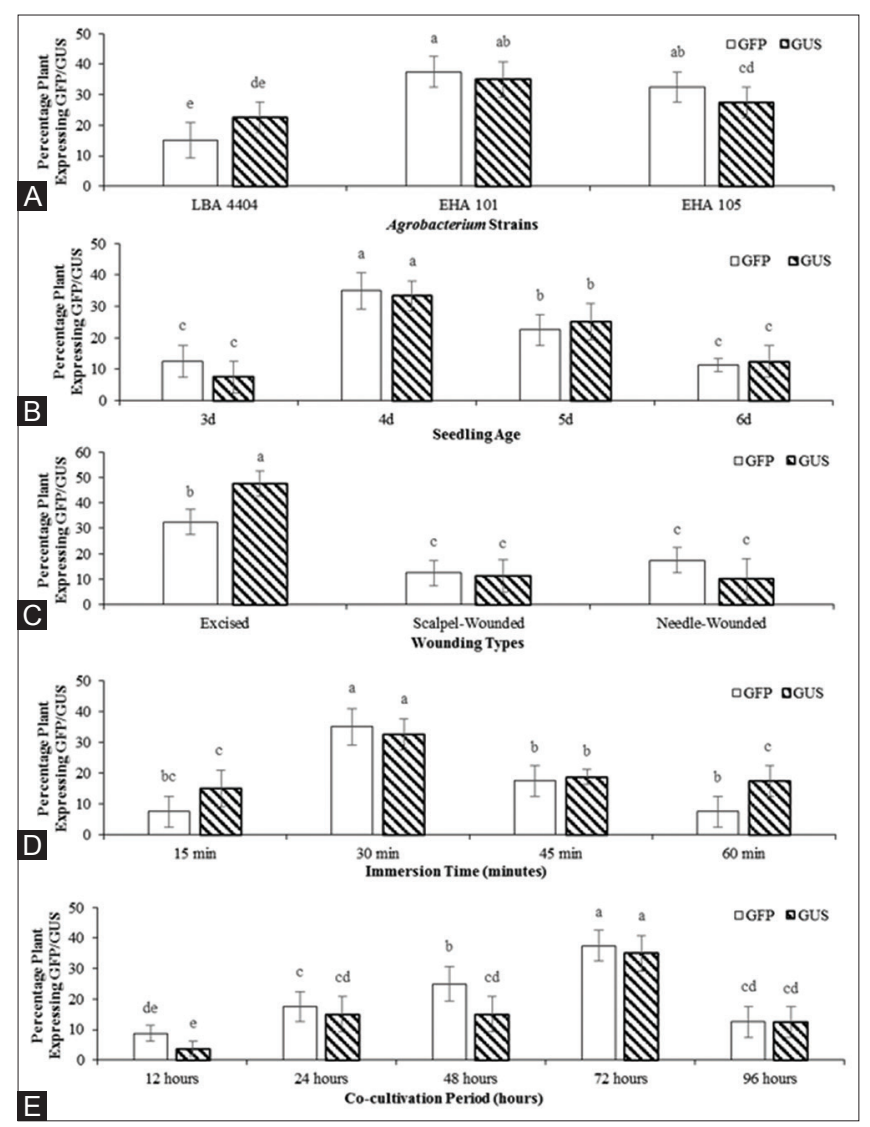

Fig 4. Effects of (A) Agrobacterium strains, (B) seedling age, (C) wounding types, (D) immersion time and (E) co-cultivation period on the percentage of plants transiently expressing GFP and GUS after 3 days of cocultivation. Data represents mean \pm standard deviation $(n=15)$. Different letters indicate the values are significantly different $(p \leq 0.05)$.

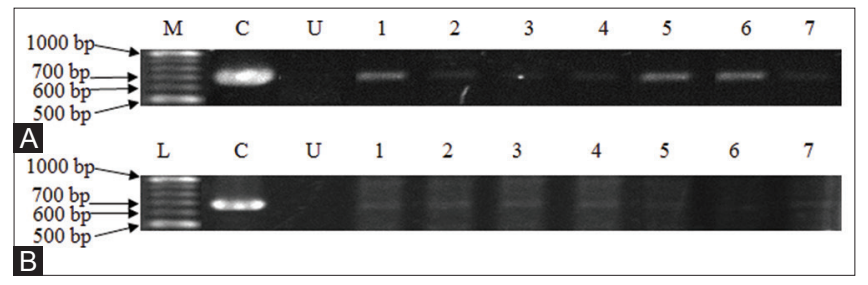

Fig 5. The PCR product of (A) GFP ( 678 bp) and (B) GUS ( 640 bp) using mGFP and GUSA specific primers. The PCR product was electrophoresed on $0.8 \%$ (w/v) agarose gel. Lane M: 100 bp PLUS DNA ladder (Fermentas, USA); C: Plasmid DNA and U: Genomic DNA from untransformed plants. The numbered lanes represents the putative transformed lines.

axillary shoots with the highest fresh and dry weight. The use of TDZ as a phenylurea type cytokinin was often reported to facilitate callus formation, callus regeneration and shoot multiplication from meristematic tissues in various plant species (Schulze, 2007; Sivanesan et al., 2008). TDZ was effectively used at lower concentrations as compared to amino purine cytokinins and was found to be less susceptible to endogenous plant hormone degrading enzymes such as cytokinin oxidase (van Staden et al., 2008). Moreover, TDZ has also been known to be 


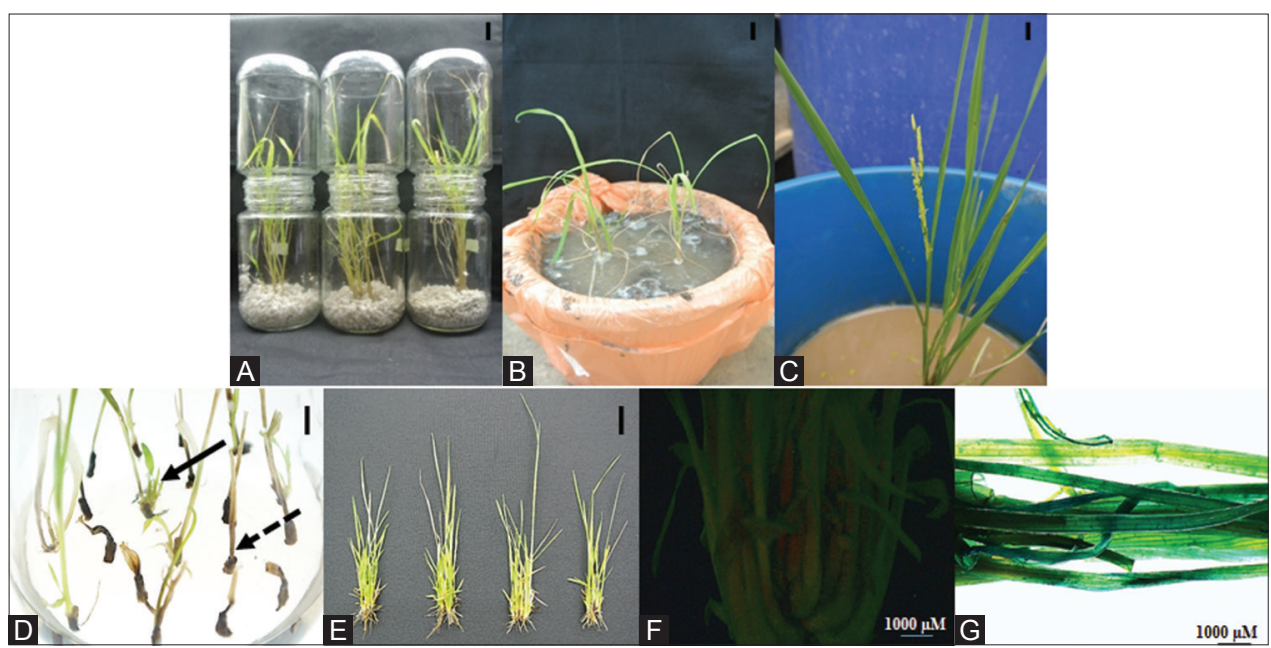

Fig 6. The acclimatization process of in-vitro cultured rice shoots, hygromycin selection and GFP/GUS expression of rice transformants. (A) Shoots were hardened for 2 weeks in enclosed culture bottles supplemented with Yoshida's solution and sterilized perlite. (B) Hardened plants were transferred into a small claypot $(12.5 \mathrm{~cm} \times 17.5 \mathrm{~cm})$ for acclimatization in the glasshouse for the first 2 weeks. (C) Acclimatized rice plants planted in a bigger pot $(38.0 \mathrm{~cm} \times 30.0 \mathrm{~cm})$ to provide room for growth. (D) Non-transformants were depicted as necrotic plants (dotted arrow) whilst green and proliferating shoots survived (single arrow) in $20 \mathrm{mg} / \mathrm{l}$ of hygromycin media. (E) Survived shoot apices transferred to solid media supplemented with $200 \mathrm{mg} / \mathrm{l}$ cefotaxime and $4 \mathrm{mg} / \mathrm{l} \mathrm{KIN}$ for 1 month of shoot multiplication. Stable (F) GFP and (G) GUS expression in multiple shoots induced from single transformed shoot apices. GFP and GUS image was taken at 8x magnification under fluorescence microscope and light stereomicroscope respectively. Bar represents $1 \mathrm{~cm}$.

involved in the synthesis or accumulation of endogenous cytokinins in the plant tissues thereby encouraging profuse shoot multiplication (Lincy and Sasikumar, 2010). A concentration of $4 \mathrm{mg} / \mathrm{L}$ of TDZ was used effectively in producing the most number of shoots from shoot apices of two indica cultivars - KDML105 (Yookongkaew et al., 2007) and IR64 (Dey et al., 2012). Both studies were in agreement with this study in which the optimal TDZ concentration was $4 \mathrm{mg} / \mathrm{L}$ and an overall shorter shoot height was observed in indica cultivar MR219. In other words, TDZ was suggested to be a genotype-independent cytokinin since Dey et al. (2012) reported that they were no significant differences on the mean shoot numbers in eight other indica rice varieties. Nonetheless, increased TDZ concentration has greatly reduced the number of axillary rice shoots, fresh and dry weight of the in-vitro rice shoots (Dey et al., 2012). Similar findings also explained that high concentrations of TDZ could be deleterious and the shoots produced were weak, fasciated and morphologically distorted (Subotić et al., 2008; Guo et al., 2011).

On the other hand, the aminopurine-based cytokinins such as KIN and BAP produced the relatively similar amount of shoots albeit lower than TDZ. Both KIN and BAP also produced higher shoot height since TDZ was known to produce shorter plantlets as well as suppressing shoot elongation (Tomsone et al., 2004; Victório et al., 2012). Several studies have also opted BAP and KIN for rice shoot multiplication because both cytokinins were more cost effective as compared to TDZ. Previous findings by Silvarajan et al. (2011) utilized KIN for multiple shoot induction from shoot apices of MR219 but the survival rate of such target tissue was very low during the preinduction step in liquid medium before the shoots were multiplied in solid medium. Thus, the present study has proven to be a more efficient and rapid method in which shoot apices were directly cultured into the solid media for multiplication. Furthermore, Roy and Mandal (2006) also utilized $4 \mathrm{mg} / \mathrm{L} \mathrm{KIN}$ to multiply plantlets regenerated from calli of indica cv. IR72 as compared to BAP. Roy and Mandal (2011) then further described BAP at 4 to $8 \mathrm{mg} / \mathrm{L}$ was inhibitory for shoot development. In contrast, Puhan and Siddiq (2013) used shoot apices derived from two weeks old in-vitro primary tillers of rice and three to five shoots were formed from all twelve different rice varieties composing of indica, japonica, aromatic and wild rice in MS supplemented with $0.5 \mathrm{mg} / \mathrm{L}$ of BAP instead of KIN. Regeneration of MR219 mutant line 4 rice calli and subsequently, shoot multiplication was also performed in optimized MS media augmented with $2 \mathrm{mg} / \mathrm{L}(10 \mu \mathrm{M})$ BAP (Htwe et al., 2011).

Cytokinin was also reported to activate the synthesis of chlorophyll pigments and photosynthetic apparatus (Kulaeva et al., 2002; Oliveira et al., 2008). In in-vitro shoot cultures of Annona gabra L., KIN and BAP were found to increase the shoots' chlorophyll content with KIN being reported to increase more than $30 \%$ of chlorophyll a and b. However, shoots cultured in TDZ media showed diminished chlorophyll content with irregular shapes and sizes of chloroplasts and a reduction in thylakoid membranes thereby causing lower photosynthetic activity 
than shoots produced in KIN and BAP (Oliveira et al., 2008). These findings were in agreement with this study in which KIN and BAP produced shoots with significantly higher total chlorophyll content whereas shoots produced in TDZ contained the least chlorophyll content. In particular, KIN produced shoots with 2 to 3 fold higher in chlorophyll content than BAP and TDZ as shown in this study. The ability of KIN to regulate the development and maintenance of chloroplasts and photosynthetic organelles has improved the overall plant vigour and stress resistance (Alsokari, 2009; Aldesuquy et al., 2014). Jamei et al. (2008) further elaborated that the activity of the 5 -aminolevulinic acid dehydratase (ALA-D) was increased when KIN was applied exogenously to maize seedlings. The ALA-D enzyme catalyzed the porphyrin ring formation which was used in chlorophyll and cytochrome synthesis. Explants cultivated with BAP and KIN also showed a higher accumulation of nitrogen resulting in thicker, darker green leaves as well as higher dry weight comparing to TDZ and ZEA (Oliveira et al., 2010). To conclude, KIN could be a potential cytokinin in multiplying in-vitro rice shoots with higher chlorophyll content which was associated with better plant vigour and quality.

The crosstalk between the transport and metabolism of carbohydrate and phytohormone signaling during plant development has always been a research topic that has yet to be fully understood (Eveland and Jackson, 2012). Early findings by Roitch and Ehne $\beta$ (2000) revealed that cytokinin such as the phenylurea TDZ as well as the adenine-derived cytokinins BAP and KIN were shown to induce higher invertase, sucrose synthase, hexose and sucrose transporters activities. TDZ was reported to induce higher level invertase mRNA expression when compared to BAP and KIN (Roitch and Ehne $\beta$, 2000) which could explain the higher total soluble sugar content in TDZ proliferated shoots as reported in this study. As sucrose is the major transport form of fixed carbon from the phloem into the sink tissues, the expression of these enzymes led to an increase of soluble sugars uptake and hence, the increased soluble sugar content (especially glucose) found in the actively developing tissues (Panigrahi et al., 2007; Lee and Huang, 2013). Besides that, the biological activity of cytokinins as growth regulators was to stimulate protein synthesis which then promote cell division and morphogenesis (van Staden et al., 2008). It was expected that optimal concentrations of the three cytokinins with the highest amount shoots produced will contain the higher soluble protein content but this was not the case in this study. Similarly, the total soluble protein content also remained relatively constant in in-vitro shoots induced from cuttings of Dioscorea species (Chu et al., 2002).

KIN was selected as a suitable cytokinin due to its ability to produce relatively high number of shoots than BAP, but lower than TDZ. Even though the fresh weight of in-vitro shoots cultured in KIN media was slightly lower than BAP and TDZ, the total chlorophyll content of the shoots remained the highest at all tested concentrations of 1 to $6 \mathrm{mg} / \mathrm{L}$. In-vitro shoots also contained relatively high total soluble sugar content in media supplemented with KIN than BAP but lower than TDZ. This implied that the metabolism and transport of soluble sugars for shoot formation was relatively efficient for KIN. Taken together, KIN is suitable for the production of quality in-vitro MR219 shoots. In-vitro shoots induced from KIN supplemented MS media were also successfully hardened and acclimatized in the greenhouse as depicted in Fig. 6A - C.

Different Agrobacterium strains contained different chromosomal background and vir-helper plasmids that determined their virulence and the transformation efficiency of rice. The high percentage GFP and GUS expression as achieved by EHA101 could be due to the increased induction of additional vir genes (vir $G$ and $\operatorname{vir} A$ ) found in the pTiBo542 plasmid (Gelvin, 2003). Several monocotyledonous plants such as banana (Sreeramanan et al., 2006), orchid (Sreeramanan and Zuraida, 2010) and maize (Ombori et al., 2013) demonstrated improved transformed efficiencies when EHA101 strain were used as compared to LBA4404 strain. The virulent EHA101 strain was also used to transform the recalcitrant indica rice varieties (Shri et al., 2013).

Young and actively dividing cells are favourite anchor sites for Agrobacterium. As an example, shoot apex and calli of Sorgbum bicolor were considered as desirable explants over leaves because the matured epidermis cells in leaves lacked of actively dividing cells for Agrobacterium attachment (Verma et al., 2008). As young and active plant cells synthesized cell walls, various chemical compounds derived from the phenylpropanoid pathway (coniferyl alcohol, sinapyl alcohol, sinapic acid and ferulic acid) was also produced and utilized by Agrobacterium as vir inducers for infection (Mandal et al., 2010; Miedes et al., 2014). However, in old and young explants, necrotic symptom was observed as a result of hypersensitivity response towards Agrobacterium infection (Arcos-Ortega et al., 2010). Necrotic tissues were known to accumulate antimicrobial substances that might inhibit Agrobacterium attachment (Kuta and Tripathi, 2005). In other words, selection of a proper explant age was necessary to ensure that transformation efficiency was not compromised. In this case, shoot apices derived from 4 days old rice seedlings were found to be suitable explants for transformation whereas explants derived from 3, 5 and 6 days old seedlings were found to be necrotic after 3 days of co-cultivation.

Prior to T-DNA transfer into rice shoot apices, the mobility, chemotaxis response and the bacterial attachment 
of the Agrobacterium are the most essential steps during a transformation event (Merritt et al., 2007; Uddain et al., 2015). Many studies have taken explant wounding as a routine practice presumably because vir inducers were produced at the host plant wounded sites which acted as chemo-attractants for Agrobacterium attachment (Simoh et al., 2007, Zia et al., 2010). While this might be true, additional wounding of rice shoot apices did not result in high percentage expression of the reporter genes. Excising germinated rice seedlings to expose the shoot apical meristem region was considered as a wounding effect. Deliberate explant wounding have considerably increased the number of explants showing necrotic symptoms which has subsequently led to lower regeneration rates (Rajagopalan and Perl-Treves, 2005). Wounded tissues of monocots were also found to actively differentiate into lignified or sclerified cells which blocked Agrobacterium from invading the wounded sites. This rapid differentiation of wounded tissues left only a handful of cells marginally transformed (Sood et al., 2011). Ethylene production in response to plant wounding, biotic and abiotic stress has been a common phenomenon (Wang et al., 2002) but the production of this simple two-carbon compound has elicited the host plant response to suppress the activation of Agrobacterium's virgene. Fortunately, the inhibitory effect of ethylene can be relieved by the supplementation of vir inducers such as acetosyringone (Nonaka et al., 2008). Plants from the Gramineae, including maize also tend to produce 2-hydroxy-4,7-dimethyloxybenzoxazin-3-one (MDIBOA), a major organic exudate of the maize seedling roots, that inhibited the growth of Agrobacterium and the induction of vir gene expression system (Sahi et al., 1990; Zhang et al., 2000; Tzfira and Citovsky, 2002). All these factors could have contributed to the low expression of the reporter genes in scalpel and needle wounded rice shoot apices.

Optimizing the Agrobacterium immersion time is another crucial step so as to allow time for the formation bacterial biofilm and the adherence of Agrobacterium before T-DNA transfer occur during co-cultivation stage (Merritt et al., 2007). Gnasekaran et al. (2014) explained that shorter immersion time and light agitation at $70 \mathrm{rpm}$ has reduced the number of Agrobacterium cells attached to the PLBs of $V$ anda orchid and hence, GUS expression was the lowest. In this study as well, a brief 15 minutes of bacterial immersion did not result in higher GFP and GUS expression for rice shoot apices when compared to the optimal 30 minutes of immersion. Besides that, genotypic variations was thought to influence the immersion time needed to infect indica rice shoot apices of different cultivars. A 30 minutes of immersion period was needed for indica IR64 which was in accordance with this current study (Dey et al., 2012). However, a relatively brief immersion time was only needed for indica varieties white ponni (10 minutes), pusa basmati 1 (10 minutes) and KDML105 (1 minute) (Arockiasamy and Ignacimuthu, 2007; Yookongkaew et al., 2007). Longer immersion time has always been associated with bacterial overgrowth, necrotic explants and reduced explant regeneration rate especially after transferring them into co-cultivation medium. Wang et al. (2007), in his study to employ specific GFP constructs to monitor the Agrobacterium attachment on leaf segments in planta, discovered that the increment of bacterial attachment and cell numbers was distinct from 12 hours to 24 hours and then reached its saturation point by 24 hours. When the number of bacteria cells increased overtime due to long immersion period, most transformation studies has experienced bacteria overgrowth that eventually killed the explants during the co-cultivation stage (Guo et al., 2012). Similarly, rice shoot apices was killed by bacterial overgrowth as the bacterial immersion increased from 45 to 60 minutes.

In general, 2-7 days of co-cultivation is considered as suitable for transformation (Huang and Wei, 2005) in which longer periods of co-culture could enhance T-DNA transfer into plant cells. For instance, Mukeshimana et al. (2013) recorded 8 days co-cultivation period needed to achieve $76.5 \%$ of transient GUS expression for Phaseolus vulgaris L. while Fitch et al. (2011) generated a staggering amount of 466 transgenic lines of Anthurium flowers through 10 to 14 days of co-cultivation. In spite of that, extended co-cultivation period for 96 hours (4 days) did not seem to improve the percentage of explants expressing GFP or GUS since prolonged co-culturing has led to severe bacterial overgrowth which eventually caused explant death. Such observations was congruent in other plant species in which longer co-cultivation period led to necrotic plants, lower regeneration rates, lower transformation efficiency and severe bacterial contamination during the selection stage (Devi et al., 2012; Yang et al., 2013a; Yang et al., 2013b). Based on this study, 3 days of co-cultivation period was found to be optimal which was in correspondence with previous studies. Primary and secondary embryogenic calli derived from mature seeds (Saika and Toki, 2010; Krishnan et al., 2013) and also shoot apex (Ariockiasamy and Ignacimuthu, 2007; Yookongkaew et al., 2007) were co-cultivated for at least 2 to 3 days before transferring them into selection media.

In conclusion, this study has successfully established efficient in-vitro shoot regeneration and transformation procedure for the recalcitrant MR219 shoot apices with transformation efficiency of $5.83 \%$ (Fig. 6). This study has provided a fundamental platform for future genetic transformation of recalcitrant indica varieties which is of utmost importance to ensure reproducible and efficient production of transgenic rice engineered with desired traits. 


\section{ACKNOWLEDGEMENTS}

The authors would like to thank National LRGS Food Security Programme - "Enhancing Sustainable Rice Production through Innovative Research" for the research funding and Graduate Research Fellowship (UPM-GRF) for the scholarship.

\section{Author's contribution}

Clement Wong Kiing Fook conducted the study, collected and analyzed the data and prepared the manuscript. Maziah Mahmood designed, supervised the overall study as well as reviewed the paper. Lai Kok Song and Wong Mui Yun reviewed and improvised the paper.

\section{REFERENCES}

Ahmed, M., F. Malek, B. R. Ahmad, M. Rahman and M. K. Juni. 2011. Disinfestation of Rhyzopertha dominica (F.) using microwave heat treatment to the Malaysian paddy. Int. J. Agri. Biosystems Sci. Eng. 5: 4-9.

Alam, I., S. A. Sharmin, M. K. Naher, M. J. Alam, M. Anisuzzaman and M. F. Alam. 2013. Elimination and detection of viruses in meristem-derived plantlets of sweet potato as a low-cost option toward commercialization. 3 Biotechnology. 3: 153-164.

Aldesuquy, H., Z. Baka and B. Mickky. 2014. Kinetin and spermine mediated induction of salt tolerance in wheat plants: Leaf area, photosynthesis and chloroplast ultrastructure of flag leaf at ear emergence. Egypt. J. Basic Appl. Sci. 1: 77-87.

Alias, I. 2002. MR 219, a new high-yielding rice variety of more than $10 \mathrm{mt} / \mathrm{ha}$. FFTC: An International Information Center for Small Scale Farmers in Asian and Pacific Region. Mardi, Malaysia.

Alsokari, S. S. 2011. Synergistic effect of kinetin and spermine on some physiological aspects of seawater stressed Vigna sinensis plants. Saudi J. Biol. Sci. 18: 37-44.

Altpeter, F., N. Baisakh, R. Beachy, R. Bock, T. Capell, P. Christou, H. Daniell, K. Datta, S. Datta, P. J. Dix, C. Fauquet, N. Huang, A. Kohli, H. Mooibroek, L. Nicholson, T. T. Nguyen, G. Nugent, K. Raemakers, A. Romano, D. A. Somers, E. Stoger, N. Taylor and R. Visser. 2005. Particle bombardment and the genetic enhancement of crops: Myths and realities. Mol. Breed. 15: 305-327.

Arcos-Ortega, G. F., R. A. Chan-Kuuk, W. A. González-Kantún, R. Souza-Perera, Y. E. Nakazawa Ueji, E. Avilés-Berzunza, G. Godoy-Hernandez, M. A. Lawton and J. J. Zúñiga Aguilar. 2010. Agrobacterium tumefaciens - Transient genetic transformation of Habanero pepper (Capsicum chinense Jacq.) leaf explants. Electron. J. Biotechnol. 13: 9.

Arockiasamy, S. and S. Ignacimuthu. 2007. Regeneration of transgenic plants from two indica rice (Oryza sativa L.) cultivars using shoot apex explants. Plant Cell Rep. 26: 1745-1753.

Arnon, D. I. 1949. Copper enzymes in isolated chloroplasts: Polyphenoloxidase in Beta vulgaris. Plant Physiol. 24: 1-15.

Atak, C. and O. Celik. 2009. Micropropagation on Anthurium andraeanum from leaf explants. Pak. J. Bot. 41: 1155-1161.

Badoni, A. and J. S. Chauhan. 2009. Effect of growth regulators on meristem-tip development and in-vitro multiplication of potato cultivar 'Kufri Hilmalini'. Nat. Sci. 7: 31-34.

Bairu, M. W., A. O. Aremu and J. Staden. 2010. Somaclonal variation in plants: Causes and detection methods. Plant Growth Regul. 63: 147-173.

Bakshi, S. and D. Dewan. 2013. Status of transgenic crops: A review. Cloning Transgenes. 3: 119.

Bradford, M. M. 1976. A rapid and sensitive method for the quantitation of microgram quantities of protein utilizing the principle of protein-dye binding. Anal. Biochem. 72: 248-254.

Chu, E. P., C. R. De and F. Ribeiro. 2002. Growth and carbohydrate changes in shoot cultures of Dioscorea species as influenced by photoperiod, exogenous sucrose and cytokinin concentrations. Plant Cell Tissue Organ Cult. 70: 241-249.

Danilova, S. A. 2007. The technologies for genetic transformation of cereals. Russ. J. Plant Physiol. 54: 569-581.

Dawe, D. 2008. Have recent increases in international cereal prices transmitted to domestic economies? The experience of seven large Asian countries. ESA working paper No. 08-03, Agricultural Development Economics Division, the Food and Agriculture Organization of the United Nations, Rome.

Devi, R., M. S. Dhaliwal and S. S. Gosal. 2012. A simple and efficient Agrobacterium mediated transformation of tomato. Veg. Sci. 39: 113-117.

Dey, M., S. Bakshi, G. Galiba, L. Sahoo and S. K. Panda. 2012. Development of a genotype independent and transformation amenable regeneration system from shoot apex in rice (Oryza sativa spp. indica) using TDZ. 3 Biotechnology. 2: 233-240.

Eveland, A.L. and D. P. Jackson. 2012. Sugars, signalling, and plant development. J. Exp. Bot. 63: 3367-3377.

Fitch, M. M. M., T. C. W. Leong, X. He, H. R. K. Mccafferty, J. Y. Zhu, P. H. Moore, D. Gonsalves, H. S. Aldwinckle and H. J. Atkinson. 2011. Improved transformation of Anthurium. Hort. Sci. 46: 358-364.

Gamborg, O. L. 2002. Plant tissue culture: Biotechnology milestones. In Vitro Cell Dev. Biol. 38: 84-92.

Gelvin, S. B. 2003. Agrobacterium-mediated plant transformation: The biology behind the "gene jockeying" tool. Microbiol. Mol. Biol. Rev. 67: 16-37.

Gnasekaran, P., J. J. J. Antony, J. Uddain and S. Subramaniam. 2014. Agrobacterium mediated transformation of the recalcitrant Vanda Kasem's Delight orchid with higher efficiency. Sci. World J. 2014: 583934.

Guo, B., B. H. Abbasi, A. Zeb, L. L. Xu and Y. H. Wei. 2011. Thidiazuron : A multi-dimensional plant growth regulator. Afr. J. Biotechnol. 10: 8984-9000.

Guo, M., Y. L. Zhang, Z. J. Meng and J. Jiang. 2012. Optimization of factors affecting Agrobacterium-mediated transformation of Micro-Tom tomatoes. Genet. Mol. Res. 11: 661-71.

Huang, X. and Z. Wei. 2005. Successful Agrobacterium-mediated genetic transformation of maize elite inbred lines. Plant Cell Tissue Organ Cult. 83: 187-200.

Hwte, N. N., M. Maziah, C. L. Ho, Q. Z. Faridah and M. Z. Abdullah. 2011. Responses of some selected Malaysian rice genotypes to callus induction under in vitro salt stress. Afr. J. Biotechnol. 10: 350-362.

Jamei, R., R. Heidari, J. Khara and S. Zare. 2008. The interaction effects of flooding and kinetin on growth criteria, chlorophyll content, and 5-aminolevulinic acid dehydratase activity in corn seedlings. Turk. J. Biol. 32: 253-257.

Jefferson, R. A., T. A. Kavanagh and M. W. Bevan. 1987. GUS fusions: $\beta$-glucuronidase as a sensitive and versatile gene fusion marker in higher plants. EMBO J. 6: 3901-3907.

Ji, Q., X. Xu and K. Wang. 2013. Genetic transformation of major cereal crops. Int. J. Dev. Biol. 57: 495-508. 
Krishnan, S., A. Priya and M. Ramesh. 2013. Rapid regeneration and ploidy stability of "cv IR36" indica rice (Oryza sativa. L) confers efficient protocol for in vitro callus organogenesis and Agrobacterium tumefaciens mediated transformation. Bot. Stud. 54: 47.

Kulaeva, O. N., E. A. Burkhanova, N. N. Karavaiko, S. Y. Selivankina, S. A. Porfirova, G. M. Galina, Y. V. Zemylachenko and T. Börner. 2002. Chloroplasts affect the leaf response to cytokinin. J. Plant Physiol. 159: 1309-1316.

Kuta, D. D. and L. Tripathi. 2005. Agrobacterium-induced hypersensitive necrotic reaction in plant cells: A resistance response against Agrobacterium-mediated DNA transfer. Afr. J. Biotechnol. 4: 752-757.

Lee, S. T. and W. L. Huang. 2013. Cytokinin, auxin, and abscisic acid affects sucrose metabolism conduce to de novo shoot organogenesis in rice (Oryza sativa L.) callus. Bot. Stud. 54: 5.

Lincy, A. and B. Sasikumar. 2010. Enhanced adventitious shoot regeneration from aerial stem explants of ginger using TDZ and its histological studies. Turk. J. Bot. 34: 21-29.

Liew, Y. A., S. R. Syed Omar, M. H. A. Husni, A. M. A. Zainal and P. A. Nur Ashikin. 2012. Effects of foliar applied copper and boron on fungal diseases and rice yield on cultivar MR219. Pertanika J. Trop. Agric. Sci. 35: 339-349.

Mandal, S. M., D. Chakraborty and S. Dey. 2010. Phenolic acids act as signaling molecules in plant microbe symbioses. Plant Signal Behav. 5: 359-368.

Merritt, P. M., T. Danhorn and C. Fuqua. 2007. Motility and chemotaxis in Agrobacterium tumefaciens surface attachment and biofilm formation. J. Bacteriol. 189: 8005-8014.

Miedes, E., R. Vanholme, W. Boerjan and A. Molina. 2014. The role of the secondary cell wall in plant resistance to pathogens. Front. Plant. Sci. 5: 1-13.

Mukeshimana, G., Y. Ma, A. E. Walworth, G. Song and J. D. Kelly. 2012. Factors influencing regeneration and Agrobacterium tumefaciens-mediated transformation of common bean (Phaseolus vulgaris L.). Plant Biotechnol. Rep. 7: 59-70.

Murashige, T. and F. Skoog. 1962. A revised medium for rapid growth and bioassays with tobacco tissue cultures. Physiol. Plant. 15: 473-497.

Nelson, N. 1944. A photometric adaptation of the Somogyi method for the determination of glucose. J. Biol. Chem. 153: 375-380.

Nonaka, S., K. I. Yuhashi, K. Takada, M. Sugaware, K. Minamisawa and $\mathrm{H}$. Ezura. 2008. Ethylene production in plants during transformation suppresses vir gene expression in Agrobacterium tumefaciens. N. Phytol. 178: 647-656.

Ombori, O., J. V. O. Muoma and J. Machuka. 2012. Agrobacteriummediated genetic transformation of selected tropical inbred and hybrid maize (Zea mays L.) lines. Plant Cell Tissue Organ Cult. 113: 11-23.

Oliveira, L. M., R. Paiva, J. R. F. de Santana, E. Alves, R. C. Nogueira and D. F. Pereira. 2008. Effect of cytokinins on in vitro development of autotrophism and acclimatization of Annona glabra L. In Vitro Cell Dev. Biol. 44: 128-135.

Oliveira, L. M., R. Paiva, J. Raniere and J. R. F. de Santana. 2010. Effects of cytokinins on in on mineral accumulation and bud development in Annona glabra L. Ciên. Agrotecnol. 34: 1439-1445.

Panigrahi, J., M. Behera, S. Maharana and R. R. Mishra. 2007. Biomolecular changes during in vitro organogenesis of Asteracantha longifolia (L.) Nees - A medicinal herb. Indian J. Exp. Biol. 45: 911-919.

Puhan, P. and E. A. Siddiq. 2013. Protocol optimization and evaluation of rice varieties response to in vitro regeneration. Adv. Biosci. Biotechnol. 4: 647-653.

Rajagopalan, P. A. and R. Perl-Treves. 2005. Improved cucumber transformation by a modified explant dissection and selection protocol. HortScience. 40: 431-435.

Roitsch, T. and R. Ehneß. 2000. Regulation of source/sink relations by cytokinins. Plant Growth Regul. 32: 359-367.

Roy, B. and A. B. Mandal. 2006. Rapid and recurrent in vitro mass multiplication of androgenic rice embryos. Indian J. Biotechnol. 5: 239-242.

Roy, B. and A. B. Mandal. 2011. Profuse microtillering of androgenic plantlets of elite indica rice variety IR72. Asian J. Biotechnol. 3: 165-176.

Sahi, S. V., M. D. Chilton and W. S. Chilton. 1990. Corn metabolites affect growth and virulence of Agrobacterium tumefaciens. Proc. Nat. Acad. Sci. USA. 87: 3879-3883.

Saika, H. and S. Toki. 2010. Mature seed-derived callus of the model indica rice variety Kasalath is highly competent in Agrobacteriummediated transformation. Plant Cell Rep. 29: 1351-1364.

Saragih, A. A., A. B. Puteh, M. R. Ismail and M. M. A. Mondal. 2013. Pollen quality traits of cultivated (Oryza sativa L. ssp. indica) and weedy (Oryza sativa var. Nivara) rice to water stress at reproductive stage. Aust. J. Crop. Sci. 7: 1106-1112.

Schulze, J. 2007. Improvements in cereal tissue culture by thidiazuron: A review. FVCSB. 1: 64-79.

Shamsuddin, J., A. A. Elisa, M. A. R. S. Shazana and I. C. Fauziah. 2013. Rice defense mechanisms against the presence of excess amount of $\mathrm{Al}^{3+}$ and $\mathrm{Fe}^{2+}$ in the water. Aust. J. Crop Sci. 7: 314-320.

Shri, M., A. Rai, P. K. Verma, P. Misra, S. Dubey, S. Kumar, S. Verma, N. Gautam, R. D. Tripathi, P. K. Trivedi and D. Chakrabarty. 2012. An improved Agrobacterium-mediated transformation of recalcitrant indica rice (Oryza sativa L.) cultivars. Protoplasma. 250: 631-636

Silvarajan, L., R. Nulit and F. Q. Zaman. 2012. Effect of plant growth regulators on in vitro regeneration of Malaysian indica rice (Oryza sativa L.) cv. MR219 by shoot apical meristem. Asian J. Agri. Res. 6: 180-187.

Simoh, S., H. J. M. Linthorst and R. Verpoorte. 2007 Host-bacterium interactions in Agrobacterium tumefaciens-mediated plant transformation : Mechanism of action and Agrobacterium/plant factors involved. Curr. Topics Plant. Biol. 8: 1-20.

Sivanesan, I., S. J. Hwang and B. R. Jeong. 2008. Influence of plant growth regulators on axillary shoot multiplication and iron source on growth of Scrophularia takesimensis Nakai a rare endemic medicinal plant. Afr. J. Biotechnol. 7: 4484-4490.

Sood, P., A. Bhattacharya and A. Sood. 2011. Problems and possibilities of monocot transformation. Biol. Plantarum. 55: 1-15.

Sreeramanan, S., M. Maziah, M. P. Abdullah, M. Sariah and R. Xavier. 2006. Transient expression of gusA and gfp gene in Agrobacterium-mediated banana transformation using single tiny meristem bud. Asian J. Plant Sci. 3: 468-480.

Sreeramanan, S. and A. R. Zuraida. 2010. Early GFP gene assessments influencing Agrobacterium tumefaciens-mediated transformation system in Phalaenopsis violacea orchid. Emirates J. Food Agri. 22: 103-116.

Staub, J., K. Bacher and K. Poetter. 1996. Sources of potential error in the application of random polymorphic DNAs in cucumber. Hortc. Sci. 32: 262-266.

Subotić, A., S. Jevremović and D. Grubišić. 2009. Influence of cytokinins on in vitro morphogenesis in root cultures of 
Centaurium erythraea — valuable medicinal plant. Sci. Hortic. 120: 386-390.

Tomsone, S., D. Gertnere and D. Novikova. 2004. The influence of thidiazuron on shoot regeneration and proliferation of rhododendrons in vitro. Acta Univ. Lat. 676: 239-242.

Tzfira, T. and V. Citovsky. 2002. Partners-in-infection: Host proteins involved in the transformation of plant cells by Agrobacterium. Trends Cell Biol. 12(3): 121-129.

Uddain, J., L. Zakaria, B. L. Chew and S. Sreeramanan. 2015. Preliminary assessment on Agrobacterium-mediated of Dendrobium Broga Giant orchid's PLBs. Emirates J. Food Agric. 27: 669-677.

Van Staden, J., E. Zazimalova and E. F. George. 2008. Chapter 6 Plant Growth Regulators II: Cytokinins, their analogues and antagonists. In: George, E. F., M. A. Hall and G. J. De Klerk, (Ed.), Plant Propagation by Tissue Culture: Volume 1 the Background, $3^{\text {rd }}$ ed. Springer, The Netherlands, Pp. 205-226.

Verma, A., V. Nain, C. Kumari, S. K. Singh, M. Lakshmi Narasu and P. Ananda Kumar. 2008. Tissue specific response of Agrobacterium tumefaciens attachment to Sorghum bicolor (L) Moench. Physiol. Mol. Biol. 14: 307-313.

Wang, K., L. Kang, A. Anand, G. Lazarovits and K. S. Mysore. 2007. Monitoring in planta bacterial infection at both cellular and whole-plant levels using the green fluorescent protein variant GFPuv. N. Phytol. 174: 212-223.

Wang, K. L., H. Li and J. R. Ecker. 2002. Ethylene biosynthesis and signaling networks. Plant Cell. 14: 131-152.

Victório, C. P., C. Luiz and S. Lage. 2012. Tissue culture techniques in the proliferation of shoots and roots of Calendula officinalis. Rev. Ciên. Agronômica. 43: 539-545.
Yang, J., J. Yi, C. Yang and C. Li. 2013a. Agrobacterium tumefaciensmediated genetic transformation of Salix matsudana Koidz. using mature seeds. Tree Physiol. 33: 628-639.

Yang, J., B. Zhao, Y. B. Kim, C. Zhou, C. Li, Y. Chen, H. Zhang and C. H. Li. 2013b. Agrobacterium tumefaciens - Mediated transformation of Phellodendron amurense Rupr. Using matureseed explants. Mol. Biol. Rep. 40: 281-288.

Yookongkaew, N., M. Srivatanakul and J. Narangajavana. 2007. Development of genotype independent regeneration system for transformation of rice (Oryza sativa spp. indica). J. Plant. Res. 120: $237-245$

Yoshida, S., D. A. Forno, J. H. Cock and K. A. Gomez. 1976. Laboratory Manual for Plant Physiological Studies of Rice, $3^{\text {rd }}$ ed. International Rice Research Institute, Manila, Phillipines.

Zhang, J., L. Boone, R. Kocz, C. Zhang, A. N. Binns and D. G. Lynn. 2000. At the maize/Agrobacterium interface: Natural factors limiting host transformation. Chem. Biol. 7: 611-621.

Zia, M., Z. F. Rizvi, M. Zia and E. T. Al. 2010. Agrobacterium mediated transformation of soybean (Glycine max L.): Some conditions standardization. Pak. J. Bot. 42: 2269-2279.

Ziegler, R. S. and A. Barclay. 2008. The relevance of rice. Rice. 1: 3-10.

Zuraida, A. R., R. K. Zulkifli, Z. Alizah, Z. Zamri and A. Aziz. 2013. Hygromycin as selective marker in Agrobacterium-mediated genetic transformation of indica rice MR 219. J. Trop. Agric. Food Sci. 41: 71-79.

Zuraida, A. R., Z. A. Seman, N. Basirun, A. L. Julkiflie, Z. Zamri and S. Subramaniam. 2011. Preliminary investigations of Agrobacterium-mediated transformation in indica rice MR 219 embryogenic callus using gusA gene. Afr. J. Biotechnol. 10: 7805-7813. 